\title{
Thermal Aware Power Efficient Frame Buffer Design on Kintex-7 FPGA
}

\author{
Md Atiqur Rahman \\ Gyancity Research Lab \\ Dhaka, Bangladesh \\ mim_418@yahoo.com
}

\begin{abstract}
This paper presents thermal scaling techniques in order to design low power Frame Buffer. Kintex-7 FPGA is used to implement this design. It is observed at $100 \mathrm{GHz}$ device operating frequency, on scaling the temperature from $65^{\circ} \mathrm{C}$ to $-15^{\circ} \mathrm{C}$ with $250 \mathrm{LFM}$, we are achieving $71.82 \%$ reduction for Leakage Power, $4.62 \%$ reduction for Total Power and $97.34 \%$ for junction temperature. Under same frequency and temperature scaling with LFM is taken as 500, Leakage power, Total Power and Junction power is reduced up to $56.25 \%, 4.35 \%$ and $99.387 \%$ respectively.
\end{abstract}

Keywords-Thermal Aware, Frequency Scaling, FPGA, Frame Buffer, Low Power, Total Power, Ambient Temperature, Junction Temperature.

\section{INTRODUCTION}

A Frame Buffer is also said Frame Store is in fact a portion of RAM that contains a bitmap that is driven to a video display from a memory buffer that contains a complete frame of data. Color values are commonly stored in 1-bit binary, 4-bit palettized, 8-bit palettized, 16-bit high color and 24-bit true color format. Here in this paper we have designed a Frame Buffer in Kintex in 8-bit format so that our Frame Buffer allows 256 different colors.

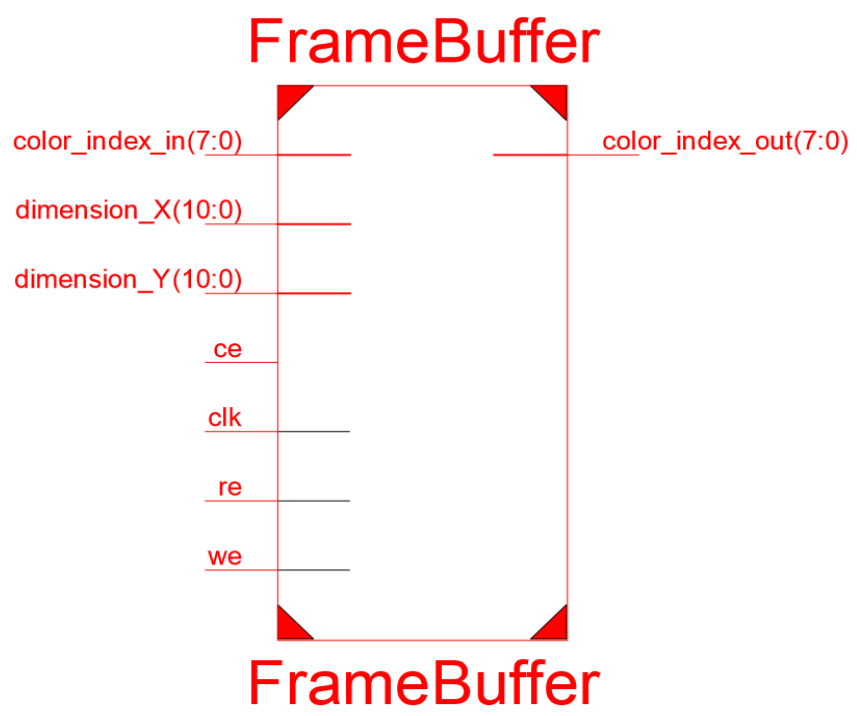

Figure 1: Top Level Schematic of Frame Buffer 
We scaled the ambient temperature as well as the frequency and found that there is a huge reduction in power consumption when we scale the frequency from $100 \mathrm{GHz}$ to $1 \mathrm{GHz}$ along with scaling the ambient temperature from $65^{\circ} \mathrm{C}$ to $-15^{\circ} \mathrm{C}$. The results have been shown in detail in the result portion. There was an important observation during experiment according to which for $1 \mathrm{THz}$ frequency we found that the Junction Temperature was exceeding the absolute maximum temperature. Due to that we have ignored the difference came for $1 \mathrm{THz}$ frequency. Figure 1 shows the Top level schematic diagram for Frame Buffer. Color_index_in, dimension_X, dimension_Y, ce, clk, re and we are the inputs for the Frame Buffer while color_index_out is the output for the Frame Buffer.

\section{LITERATURE REVIEW}

According to [1] due to signals of RGB video is not properly filtered on PCB, that causes problems in video frame buffer design. The work in [1] tells the detail about important issues of EMI regarding graphics, connector's effect, local resonance and process of filtering. In [2], for various display equipments, limited power is available and need some procedure for frame buffers for efficiently shorten the power consumption of display systems. Hybrid architecture for frame buffer is used in mobile devices in order to condense the energy requirements of display subsystems in [4].The result in [4] shows that there is 43\% reduction in energy requirements of newly designed frame buffer as compared to power DRAM frame buffer. In [6] warping module for a real time image is implemented in hardware, for that purpose reverse mapping with the use of look up table is applied to get the some relation of original image to warped image and for storing source image, frame buffer are used. In [7]Various process variation behavior is discussed based on leakage current and temperature.

\section{OUTCOMES OF THERMAL SCALING}

It is an important observation that we found no change in Clock Power, Logic Power, Signals Power and IOs Power due to thermal scaling. But there are effects of thermal scaling found on the Leakage Power, Total Power and Junction Temperature. So here in the result portion we have shown the effects. Specially in B part of the result we have shown the results found for two different Air Flow of the environment which are 250 LFM and 500 LFM.

\section{A. Clock Power, Logic Power, Signal Power and IOs Power Dissipation of Frame} Buffer for any Temperature:

Table 1: Clock Power, Logic Power \& IOs Power for different frequency in almost any ambient temperature:

\begin{tabular}{|c|c|c|c|c|}
\hline & $1 \mathrm{GHz}$ & $10 \mathrm{GHz}$ & $100 \mathrm{GHz}$ & $1 \mathrm{THz}$ \\
\hline Clock Power & 0.005 & 0.049 & 0.491 & 4.912 \\
\hline Logic Power & 0.001 & 0.004 & 0.024 & 0.227 \\
\hline Signal Power & 0.002 & 0.014 & 0.120 & 1.184 \\
\hline IOs Power & 0.030 & 0.303 & 3.029 & 30.293 \\
\hline
\end{tabular}


It is found that while we do thermal scaling then for each of $65^{\circ} \mathrm{C}, 55^{\circ} \mathrm{C}, 45^{\circ} \mathrm{C}, 35^{\circ} \mathrm{C}$, $25^{\circ} \mathrm{C}, 15^{\circ} \mathrm{C}, 5^{\circ} \mathrm{C},-5^{\circ} \mathrm{C}$ and $-15^{\circ} \mathrm{C}$ room temperature we observed $98.98 \%$ reduction in Clock Power, 95.83\% reduction in Logic Power, 98.33\% reduction in Signals Power and $99.00 \%$ reduction in IOs Power when we increased the frequency from $1 \mathrm{GHz}$ to $100 \mathrm{GHz}$ as shown in Table 1 and Figure 2. The variation in power is much more if we increase the frequency to $1 \mathrm{THz}$. But if we do so we observed that Junction Temperature exceeds absolute maximum temperature. Thus we ignore that variation for $1 \mathrm{THz}$.

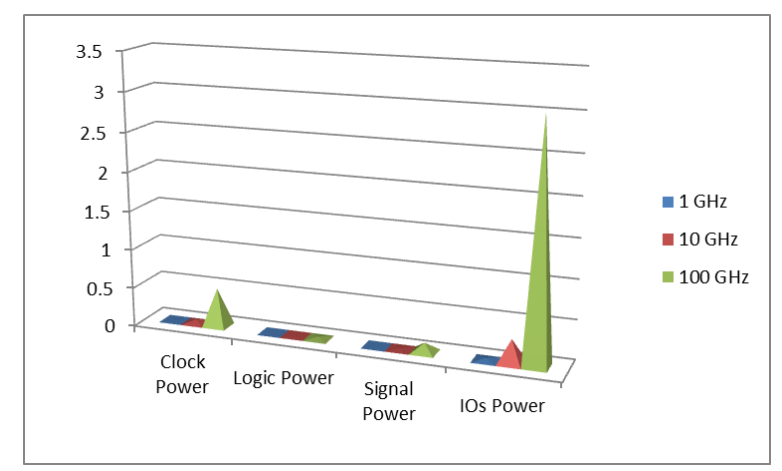

Figure 2: Clock Power, Logic Power, Signal Power \& IOs Power for different frequencies at all ambient temperature we have measured.

B. Temperature scaling to see the variance in Leakage Power, Total Power \& Junction Temperature for different frequencies.

1. Leakage Power, Total Power \& Junction Temperature when Room Temperature is $65^{\circ} \mathrm{C}$ :

Table 2: Leakage Power, Total Power \& Junction Temperature for different frequency at $65^{\circ}$ ambient temperature:

\begin{tabular}{|c|c|c|c|c|c|}
\hline & & $1 \mathrm{GHz}$ & $10 \mathrm{GHz}$ & $100 \mathrm{GHz}$ & $1 \mathrm{THz}$ \\
\hline \multirow{3}{*}{$\begin{array}{c}\text { Air } \\
\text { Flow } \\
250 \\
\text { LFM }\end{array}$} & $\begin{array}{l}\text { Leakage } \\
\text { Power }\end{array}$ & 0.161 & 0.167 & 0.252 & 0.813 \\
\hline & Total Power & 0.198 & 0.537 & 3.917 & 37.428 \\
\hline & $\begin{array}{c}\text { Junction } \\
\text { Temp }\end{array}$ & 65.9 & 67.5 & 83.0 & 125 \\
\hline \multirow{3}{*}{$\begin{array}{c}\text { Air } \\
\text { Flow } \\
500 \\
\text { LFM }\end{array}$} & $\begin{array}{l}\text { Leakage } \\
\text { Power }\end{array}$ & 0.160 & 0.166 & 0.240 & 0.813 \\
\hline & Total Power & .198 & 0.536 & 3.905 & 37.428 \\
\hline & $\begin{array}{c}\text { Junction } \\
\text { Temp }\end{array}$ & 65.9 & 67.2 & 81.2 & 125 \\
\hline
\end{tabular}

At 250 LFM Air Flow when we change the frequency from $1 \mathrm{GHz}$ to $100 \mathrm{GHz}$ at a fixed ambient temperature of $65^{\circ} \mathrm{C}$ we found $36.11 \%$ increment in Leakage Power, 94.94\% increment in Total Power and 20.60\% increment in Junction Temperature. When we changed the Air Flow to 500 LFM we found $33.33 \%$ increment in Leakage Power, 94.92\% increment in Total Power and 18.84\% increment in Junction 
Temperature for our Frame Buffer as shown in Table 2 and Figure 3. Due to the observation of Junction Temperature exceeding absolute maximum temperature results found in $1 \mathrm{THz}$ frequency is ignored.

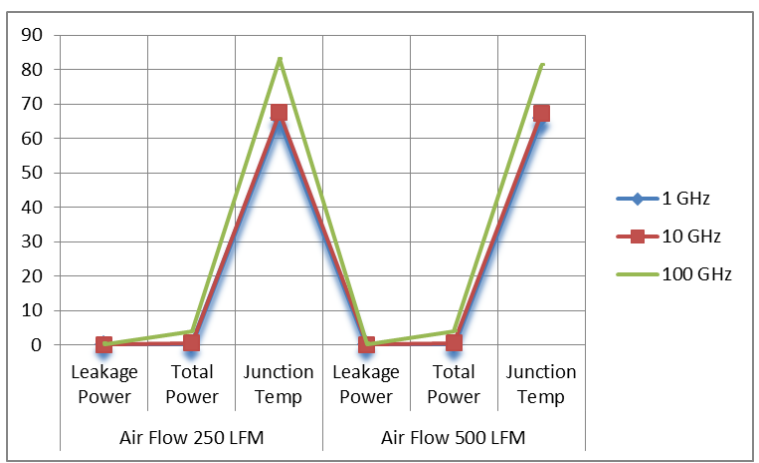

Figure 3: Leakage Power, Total Power \& Junction Temperature for different frequency at $65^{\circ}$ ambient temperature.

2. Leakage Power, Total Power \& Junction Temperature when Room Temperature is $55^{\circ} \mathrm{C}$ :

Table 3: Leakage Power, Total Power \& Junction Temperature for different frequency at $55^{\circ}$ ambient temperature:

\begin{tabular}{|c|l|l|l|l|l|}
\hline & & $1 \mathrm{GHz}$ & $10 \mathrm{GHz}$ & $100 \mathrm{GHz}$ & $1 \mathrm{THz}$ \\
\hline \multirow{2}{*}{$\begin{array}{c}\text { Air } \\
\text { Flow }\end{array}$} & $\begin{array}{c}\text { Leakage } \\
\text { Power }\end{array}$ & 0.128 & 0.132 & 0.191 & 0.813 \\
\cline { 2 - 6 } LFM & Total Power & 0.165 & 0.502 & 3.856 & 37.428 \\
\cline { 2 - 6 } & $\begin{array}{l}\text { Junction } \\
\text { Temp }\end{array}$ & 55.8 & 57.3 & 72.7 & 125 \\
\hline $\begin{array}{c}\text { Air } \\
\text { Flow } \\
500\end{array}$ & $\begin{array}{c}\text { Leakage } \\
\text { Power }\end{array}$ & 0.127 & 0.131 & 0.182 & 0.813 \\
\cline { 2 - 6 } LFM & Total Power & 0.165 & 0.501 & 3.847 & 37.428 \\
\cline { 2 - 6 } & $\begin{array}{l}\text { Junction } \\
\text { Temp }\end{array}$ & 55.7 & 57.1 & 71.0 & 125 \\
\hline
\end{tabular}

At 250 LFM Air Flow when we change the frequency from $1 \mathrm{GHz}$ to $100 \mathrm{GHz}$ at a fixed ambient temperature of $55^{\circ} \mathrm{C}$ we found $32.98 \%$ increment in Leakage Power, 95.71\% increment in Total Power and 23.24\% increment in Junction Temperature. When we changed the Air Flow to 500 LFM we found $30.21 \%$ increment in Leakage Power, $95.71 \%$ increment in Total Power and $21.54 \%$ increment in Junction Temperature for our Frame Buffer as shown in Table 3 and Figure 4. Due to the observation of Junction Temperature exceeding absolute maximum temperature results found in $1 \mathrm{THz}$ frequency is ignored. 


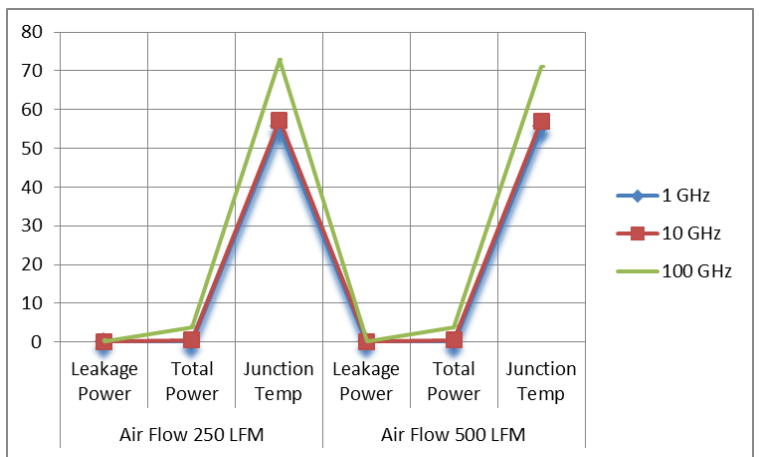

Figure 4: Leakage Power, Total Power \& Junction Temperature for different frequency at $55^{\circ}$ ambient temperature.

\section{Leakage Power, Total Power \& Junction Temperature when Room Temperature is} $45^{\circ} \mathrm{C}$ :

Table 4: Leakage Power, Total Power \& Junction Temperature for different frequency at $45^{\circ}$ ambient temperature:

\begin{tabular}{|c|c|l|l|l|l|}
\hline \multirow{2}{*}{$\begin{array}{c}\text { Air } \\
\text { Flow } \\
250\end{array}$} & $\begin{array}{c}\text { Leakage } \\
\text { Power }\end{array}$ & 0.106 & 0.109 & 0.148 & 0.813 \\
\cline { 2 - 6 } LFM & Total Power & 0.143 & 0.479 & 3.813 & 37.428 \\
\cline { 2 - 6 } & $\begin{array}{c}\text { Junction } \\
\text { Temp }\end{array}$ & 45.7 & 47.2 & 62.5 & 125 \\
\hline Air & $\begin{array}{c}\text { Leakage } \\
\text { Flow } \\
500\end{array}$ & 0.106 & 0.108 & 0.142 & 0.813 \\
\cline { 2 - 6 } PFM & Total Power & 0.143 & 0.478 & 3.808 & 37.428 \\
\cline { 2 - 6 } & $\begin{array}{c}\text { Junction } \\
\text { Temp }\end{array}$ & 45.6 & 47.0 & 60.8 & 125 \\
\hline
\end{tabular}

Again at $250 \mathrm{LFM}$ Air Flow when we change the frequency from $1 \mathrm{GHz}$ to $100 \mathrm{GHz}$ at a fixed ambient temperature of $45^{\circ} \mathrm{C}$ we found $28.37 \%$ increment in Leakage Power, 96.24\% increment in Total Power and 26.88\% increment in Junction Temperature. When we changed the Air Flow to 500 LFM we found $25.35 \%$ increment in Leakage Power, 96.24\% increment in Total Power and 25.00\% increment in Junction Temperature for our Frame Buffer as shown in Table 4 and Figure 5. Due to the observation of Junction Temperature exceeding absolute maximum temperature results found in $1 \mathrm{THz}$ frequency is ignored.

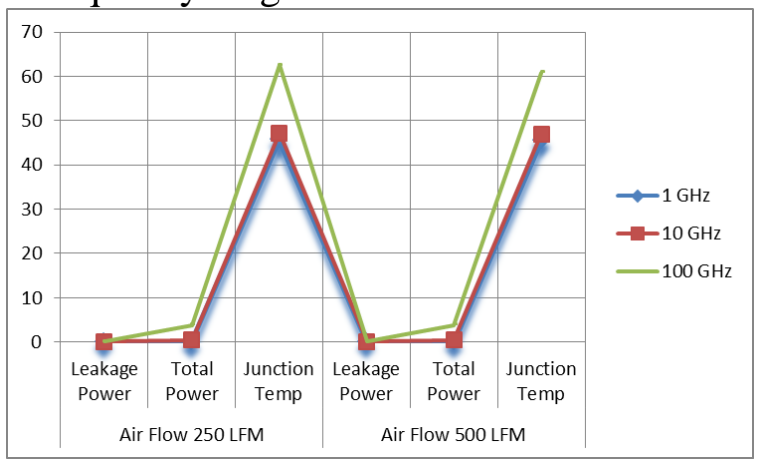

Figure 5: Leakage Power, Total Power \& Junction Temperature for different frequency at $45^{\circ}$ ambient temperature. 
4. Leakage Power, Total Power \& Junction Temperature when Room Temperature is $35^{\circ} \mathrm{C}$ :

Table 5: Leakage Power, Total Power \& Junction Temperature for different frequency at $35^{\circ}$ ambient temperature:

\begin{tabular}{|c|c|l|l|l|l|}
\hline & & $1 \mathrm{GHz}$ & $10 \mathrm{GHz}$ & $100 \mathrm{GHz}$ & $1 \mathrm{THz}$ \\
\hline Air & $\begin{array}{c}\text { Leakage } \\
\text { Flow } \\
250\end{array}$ & 0.091 & 0.093 & 0.119 & 0.813 \\
\cline { 2 - 6 } LFM & Total Power & 0.129 & 0.463 & 3.785 & 37.428 \\
\cline { 2 - 6 } & $\begin{array}{c}\text { Junction } \\
\text { Temp }\end{array}$ & 35.6 & 37.1 & 52.4 & 125 \\
\hline Air & $\begin{array}{c}\text { Leakage } \\
\text { Flow } \\
500\end{array}$ & 0.091 & 0.093 & 0.115 & 0.813 \\
\cline { 2 - 6 } LFM & Total Power & 0.129 & 0.463 & 3.781 & 37.428 \\
\cline { 2 - 6 } & $\begin{array}{c}\text { Junction } \\
\text { Temp }\end{array}$ & 35.5 & 36.9 & 50.7 & 125 \\
\hline
\end{tabular}

For $250 \mathrm{LFM}$ Air Flow when we change the frequency from $1 \mathrm{GHz}$ to $100 \mathrm{GHz}$ at a fixed ambient temperature of $35^{\circ} \mathrm{C}$ we found $23.52 \%$ increment in Leakage Power, 96.59\% increment in Total Power and 32.06\% increment in Junction Temperature. When we changed the Air Flow to 500 LFM we found $20.86 \%$ increment in Leakage Power, 96.58\% increment in Total Power and 29.98\% increment in Junction Temperature for our Frame Buffer as shown in Table 5 and Figure 6. Due to the observation of Junction Temperature exceeding absolute maximum temperature results found in $1 \mathrm{THz}$ frequency is ignored.

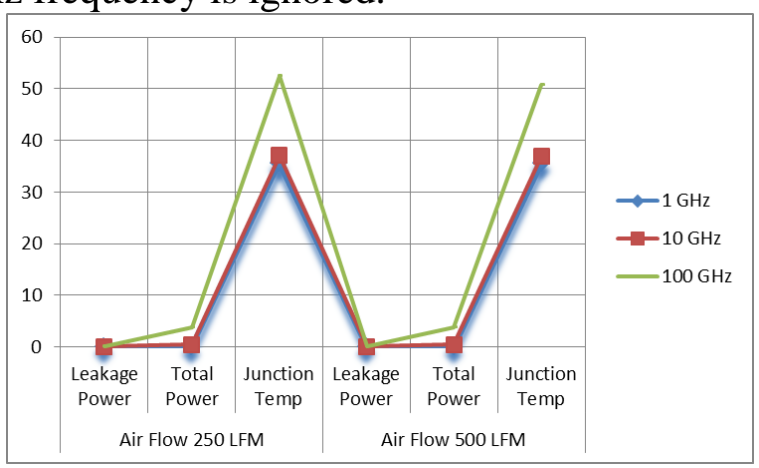

Figure 6: Leakage Power, Total Power \& Junction Temperature for different frequency at $35^{\circ}$ ambient temperature.

5. Leakage Power, Total Power \& Junction Temperature when Room Temperature is $25^{\circ} \mathrm{C}$ :

Table 6: Leakage Power, Total Power \& Junction Temperature for different frequency at $25^{\circ}$ ambient temperature:

\begin{tabular}{|c|l|l|l|l|l|}
\hline & & $1 \mathrm{GHz}$ & $10 \mathrm{GHz}$ & $100 \mathrm{GHz}$ & $1 \mathrm{THz}$ \\
\hline $\begin{array}{c}\text { Air } \\
\text { Flow } \\
250\end{array}$ & $\begin{array}{c}\text { Leakage } \\
\text { Power }\end{array}$ & 0.082 & 0.083 & 0.100 & 0.813 \\
\cline { 2 - 6 } & Total Power & 0.120 & 0.454 & 3.765 & 37.428 \\
\hline
\end{tabular}




\begin{tabular}{|c|c|l|l|l|l|}
\hline LFM & $\begin{array}{c}\text { Junction } \\
\text { Temp }\end{array}$ & 25.6 & 27.1 & 42.3 & 125 \\
\hline Air & $\begin{array}{c}\text { Leakage } \\
\text { Flow } \\
500\end{array}$ & 0.082 & 0.083 & 0.098 & 0.813 \\
\cline { 2 - 6 } LFM & Total Power & 0.120 & 0.453 & 3.763 & 37.428 \\
\cline { 2 - 6 } & $\begin{array}{c}\text { Junction } \\
\text { Temp }\end{array}$ & 25.5 & 26.9 & 40.6 & 125 \\
\hline
\end{tabular}

For $250 \mathrm{LFM}$ Air Flow when we change the frequency from $1 \mathrm{GHz}$ to $100 \mathrm{GHz}$ at a fixed ambient temperature of $25^{\circ} \mathrm{C}$ we found $18.00 \%$ increment in Leakage Power, 96.81\% increment in Total Power and 39.47\% increment in Junction Temperature. When we changed the Air Flow to 500 LFM we found $16.32 \%$ increment in Leakage Power, $96.81 \%$ increment in Total Power and 37.19\% increment in Junction Temperature for our Frame Buffer as shown in Table 6 and Figure 7. Due to the observation of Junction Temperature exceeding absolute maximum temperature results found in $1 \mathrm{THz}$ frequency is ignored.

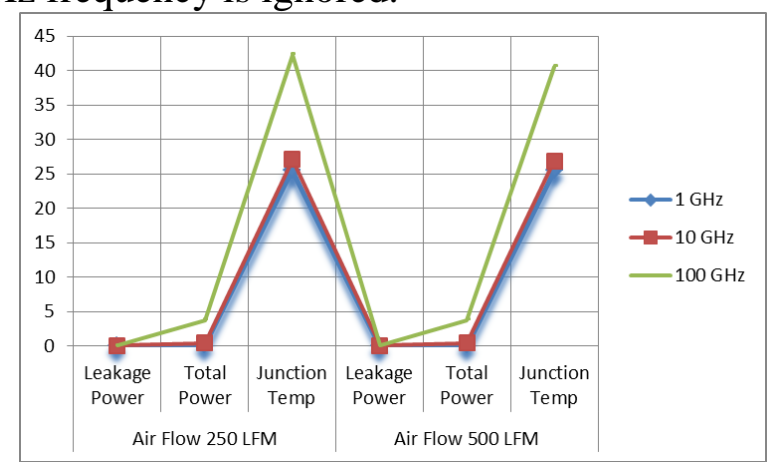

Figure 7: Leakage Power, Total Power \& Junction Temperature for different frequency at $25^{\circ}$ ambient temperature.

6. Leakage Power, Total Power \& Junction Temperature when Room Temperature is $15^{\circ} \mathrm{C}$ :

Table 7: Leakage Power, Total Power \& Junction Temperature for different frequency at $15^{\circ}$ ambient temperature:

\begin{tabular}{|c|c|c|c|c|c|}
\hline & & $1 \mathrm{GHz}$ & $10 \mathrm{GHz}$ & $100 \mathrm{GHz}$ & $1 \mathrm{THz}$ \\
\hline \multirow{3}{*}{$\begin{array}{c}\text { Air } \\
\text { Flow } \\
250 \\
\text { LFM }\end{array}$} & $\begin{array}{l}\text { Leakage } \\
\text { Power }\end{array}$ & 0.076 & 0.077 & 0.088 & 0.813 \\
\hline & Total Power & 0.114 & 0.447 & 3.753 & 37.428 \\
\hline & $\begin{array}{c}\text { Junction } \\
\text { Temp }\end{array}$ & 15.5 & 17.1 & 32.3 & 125 \\
\hline \multirow{3}{*}{$\begin{array}{c}\text { Air } \\
\text { Flow } \\
500 \\
\text { LFM }\end{array}$} & $\begin{array}{c}\text { Leakage } \\
\text { Power }\end{array}$ & 0.076 & 0.077 & 0.086 & 0.813 \\
\hline & Total Power & 0.114 & 0.447 & 3.752 & 37.428 \\
\hline & $\begin{array}{c}\text { Junction } \\
\text { Temp }\end{array}$ & 15.5 & 16.9 & 30.6 & 125 \\
\hline
\end{tabular}

For 250 LFM Air Flow when we change the frequency from $1 \mathrm{GHz}$ to $100 \mathrm{GHz}$ at a fixed ambient temperature of $15^{\circ} \mathrm{C}$ we found $13.63 \%$ increment in Leakage Power, 96.96\% increment in Total Power and 52.01\% increment in Junction Temperature. 
When we changed the Air Flow to 500 LFM we found $11.62 \%$ increment in Leakage Power, 96.96\% increment in Total Power and 49.34\% increment in Junction Temperature for our Frame Buffer as shown in Table 7 and Figure 8. Due to the observation of Junction Temperature exceeding absolute maximum temperature results found in $1 \mathrm{THz}$ frequency is ignored.

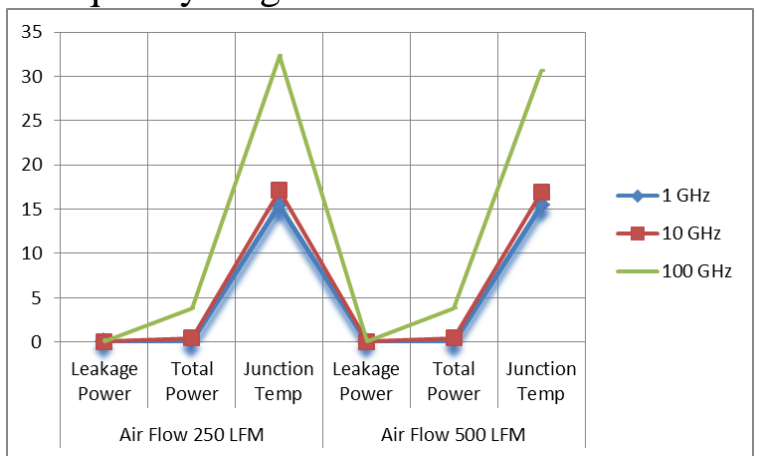

Figure 8: Leakage Power, Total Power \& Junction Temperature for different frequency at $15^{\circ}$ ambient temperature.

7. Leakage Power, Total Power \& Junction Temperature when Room Temperature is $5^{\circ} \mathrm{C}$ :

Table 8: Leakage Power, Total Power \& Junction Temperature for different frequency at $5^{\circ}$ ambient temperature:

\begin{tabular}{|c|c|l|l|l|l|}
\hline & & $1 \mathrm{GHz}$ & $10 \mathrm{GHz}$ & $100 \mathrm{GHz}$ & $1 \mathrm{THz}$ \\
\hline \multirow{2}{*}{$\begin{array}{c}\text { Air } \\
\text { Flow } \\
\text { LFM }\end{array}$} & $\begin{array}{c}\text { Leakage } \\
\text { Power }\end{array}$ & 0.072 & 0.072 & 0.080 & 0.813 \\
\cline { 2 - 6 } & Total Power & 0.109 & 0.443 & 3.745 & 37.428 \\
\cline { 2 - 6 } & $\begin{array}{c}\text { Junction } \\
\text { Temp }\end{array}$ & 5.5 & 7.0 & 22.2 & 125 \\
\hline Air & $\begin{array}{c}\text { Leakage } \\
\text { Flow } \\
500\end{array}$ & 0.072 & 0.072 & 0.079 & 0.813 \\
\cline { 2 - 6 } PFM & Total Power & 0.109 & 0.442 & 3.744 & 37.428 \\
\cline { 2 - 6 } & $\begin{array}{c}\text { Junction } \\
\text { Temp }\end{array}$ & 5.5 & 6.8 & 20.5 & 125 \\
\hline
\end{tabular}

For $250 \mathrm{LFM}$ Air Flow when we change the frequency from $1 \mathrm{GHz}$ to $100 \mathrm{GHz}$ at a fixed ambient temperature of $5^{\circ} \mathrm{C}$ we found $10.00 \%$ increment in Leakage Power, 97.08\% increment in Total Power and $75.22 \%$ increment in Junction Temperature. When we changed the Air Flow to 500 LFM we found $8.86 \%$ increment in Leakage Power, 97.08\% increment in Total Power and $73.17 \%$ increment in Junction Temperature for our Frame Buffer as shown in Table 8 and Figure 9. Due to the observation of Junction Temperature exceeding absolute maximum temperature results found in $1 \mathrm{THz}$ frequency is ignored. 


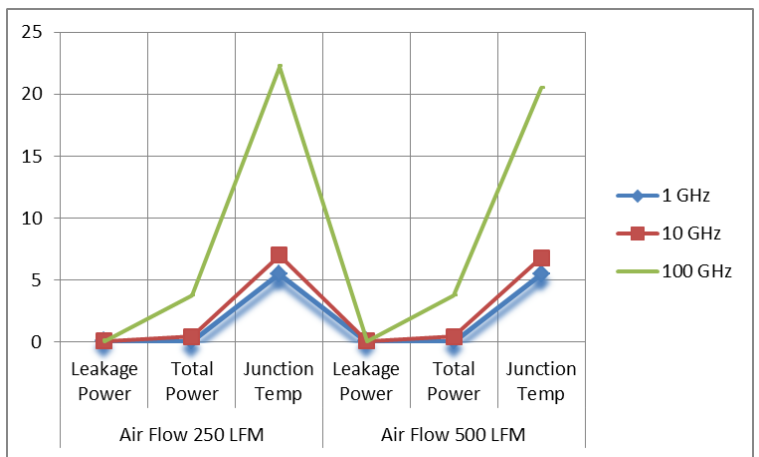

Figure 9: Leakage Power, Total Power \& Junction Temperature for different frequency at $5^{\circ}$ ambient temperature.

8. Leakage Power, Total Power \& Junction Temperature when Room Temperature is $-5^{\circ} \mathrm{C}$ :

Table 9: Leakage Power, Total Power \& Junction Temperature for different frequency at $-5^{\circ}$ ambient temperature:

\begin{tabular}{|c|c|l|l|l|l|}
\hline & & $1 \mathrm{GHz}$ & $10 \mathrm{GHz}$ & $100 \mathrm{GHz}$ & $1 \mathrm{THz}$ \\
\hline \multirow{2}{*}{$\begin{array}{c}\text { Air } \\
\text { Flow } \\
250\end{array}$} & $\begin{array}{c}\text { Leakage } \\
\text { Power }\end{array}$ & 0.068 & 0.069 & 0.075 & 0.813 \\
\cline { 2 - 6 } & Total Power & 0.106 & 0.439 & 3.740 & 37.428 \\
\cline { 2 - 6 } & $\begin{array}{c}\text { Junction } \\
\text { Temp }\end{array}$ & -4.5 & -3 & 12.2 & 125 \\
\hline Air & $\begin{array}{c}\text { Leakage } \\
\text { Flow } \\
500\end{array}$ & 0.068 & 0.069 & 0.074 & 0.813 \\
\cline { 2 - 6 } LFM & Total Power & 0.106 & 0.439 & 3.739 & 37.428 \\
\cline { 2 - 6 } & $\begin{array}{c}\text { Junction } \\
\text { Temp }\end{array}$ & -4.6 & -3.2 & 10.5 & 125 \\
\hline
\end{tabular}

For $250 \mathrm{LFM}$ Air Flow when we change the frequency from $1 \mathrm{GHz}$ to $100 \mathrm{GHz}$ at a fixed ambient temperature of $-5^{\circ} \mathrm{C}$ we found $9.33 \%$ increment in Leakage Power, 97.16\% increment in Total Power and $136.88 \%$ increment in Junction Temperature. When we changed the Air Flow to 500 LFM we found $8.10 \%$ increment in Leakage Power, 97.16\% increment in Total Power and 143.80\% increment in Junction Temperature for our Frame Buffer as shown in Table 9. Due to the observation of Junction Temperature exceeding absolute maximum temperature results for $1 \mathrm{THz}$ frequency is ignored.

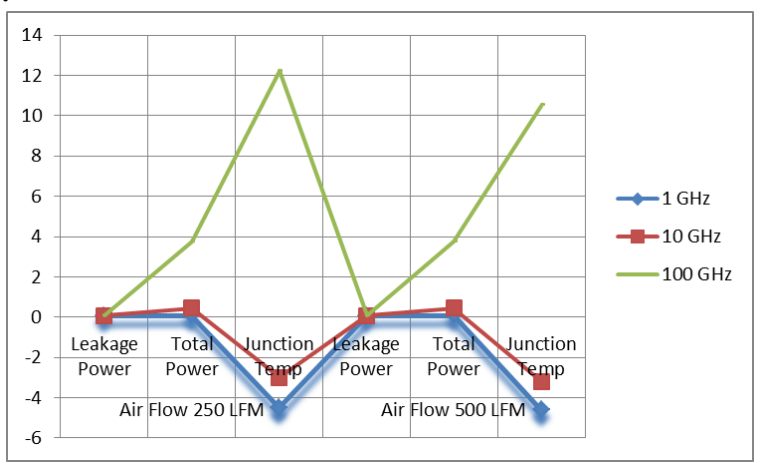


Figure 10: Leakage Power, Total Power \& Junction Temperature for different frequency at $-5^{\circ}$ ambient temperature.

9. Leakage Power, Total Power \& Junction Temperature when Room Temperature is $-15^{\circ} \mathrm{C}$ :

Table 10: Leakage Power, Total Power \& Junction Temperature for different frequency at $-15^{\circ}$ ambient temperature:

\begin{tabular}{|c|c|l|l|l|l|}
\hline \multirow{2}{*}{$\begin{array}{c}\text { Air } \\
\text { Flow } \\
250\end{array}$} & $\begin{array}{c}\text { Leakage } \\
\text { Power }\end{array}$ & 0.066 & 0.066 & 0.071 & 0.813 \\
\cline { 2 - 6 } LFM & Total Power & 0.104 & 0.437 & 3.736 & 37.428 \\
\cline { 2 - 6 } & $\begin{array}{c}\text { Junction } \\
\text { Temp }\end{array}$ & -14.5 & -13.0 & 2.2 & 125 \\
\hline Air & $\begin{array}{c}\text { Leakage } \\
\text { Flow } \\
500\end{array}$ & 0.066 & 0.066 & 0.070 & 0.813 \\
\cline { 2 - 6 } PFM & Total Power & 0.104 & 0.437 & 3.735 & 37.428 \\
\cline { 2 - 6 } & $\begin{array}{c}\text { Junction } \\
\text { Temp }\end{array}$ & -14.6 & -13.2 & 0.5 & 125 \\
\hline
\end{tabular}

Finally for 250 LFM Air Flow when we change the frequency from $1 \mathrm{GHz}$ to $100 \mathrm{GHz}$ at a fixed ambient temperature of $-15^{\circ} \mathrm{C}$ we found $7.04 \%$ increment in Leakage Power, 97.21\% increment in Total Power and $759.09 \%$ increment in Junction Temperature. When we changed the Air Flow to 500 LFM we found 5.71\% increment in Leakage Power, 97.21\% increment in Total Power and $3020.00 \%$ increment in Junction Temperature for our Frame Buffer as shown in Table 10 and Figure 10. Due to the observation of Junction Temperature exceeding absolute maximum temperature results found in $1 \mathrm{THz}$ frequency is ignored.

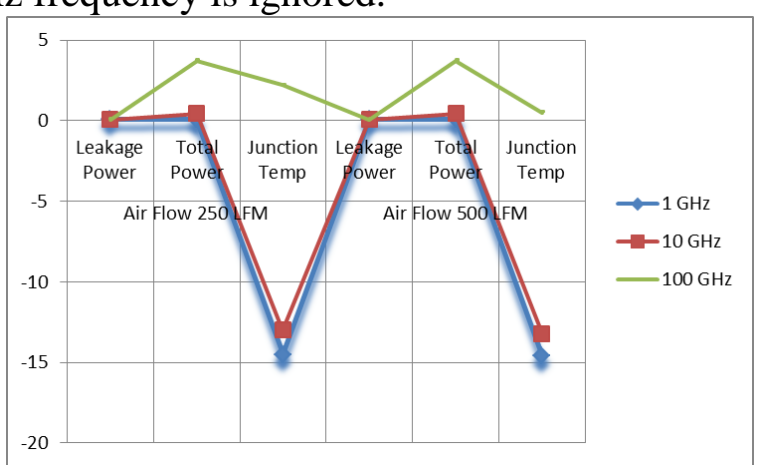

Figure 11: Leakage Power, Total Power \& Junction Temperature for different frequency at $-15^{\circ}$ ambient temperature.

\section{CONCLUSION}

Frequency scaling technique has a great impact on our Frame Buffer. Keeping the ambient temperature constant when we scaled frequency we found a great amount of reduction on Clock power, Logic power, Signals power as well as IOs power consumption which is up to $98.99 \%, 95.83 \%, 98.33 \% \& 99.00 \%$ consecutively in cases, whereas the fluctuation in Leakage power, Total power and Junction temperature consumption is a little less. The mentioned reduction in Leakage power is up to $36.11 \%$, Total power is up to $94.92 \%$ and Junction Temperature is $22 \%$ 
apparently for a $250 \mathrm{LMF}$ Air flow when the frequency is scaled from $100 \mathrm{GHz}$ to 1GHZ. On the other hand when we deal with a $500 \mathrm{LMF}$ Air flow we find a reduction of up to 34\% in Leakage power, 95\% in Total power and about 19\% in Junction temperature for positive ambient temperature. It is also observed that if we deal with negative ambient temperature then we find nearly $97-98 \%$ reduction in Total power. On scaling the temperature from $65^{\circ} \mathrm{C}$ to $-15^{\circ} \mathrm{C}$ with LFM 250 and device operating frequency is $100 \mathrm{GHz}$, there is $71.82 \%, 4.62 \%$ and $97.34 \%$ reduction in Leakage power, total power and junction temperature respectively. Under same frequency and temperature scaling scheme with 500 LFM, leakage power is reduced up to $56.25 \%$, total power is reduced up to $4.35 \%$ and junction temperature is reduced up to $99.38 \%$.

\section{FUTURE SCOPE}

This Frame Buffer has been implemented in Kintex in this paper. In future the same Frame Buffer can be implemented in Airtex 7 and Virtex. Here in this paper we have used Frequency and Thermal scaling technique. Capacitance scaling, Voltage scaling and IO scaling can be done to make it more efficient. Here in this paper we have designed a 8bit Frame Buffer to provide 256 different color schemes whereas in future there are scope to design 16-bit or more Frame Buffer.

\section{REFERENCES}

[1] S. Radu, F. Solorzano, J. Poore," EMI problems in video frame buffers design", IEEE International Symposium on Electromagnetic Compatibility, 2003 , pp. 388- 393, vol.1, 2003

[2] Hojun Shim, Naehyuck Chang, Massoud Pedram “A Compressed Frame Buffer to Reduce Display Power Consumption in Mobile Systems" http://citeseerx.ist.psu.edu/viewdoc/download?doi=10.1.1.60.8187\&rep=rep1\&type=pdf

[3] D. Burke, T. Smy, "Thermal Models for Optical Circuit Simulation Using a Finite Cloud Method and Model Reduction Techniques", IEEE Transactions on Computer-Aided Design of Integrated Circuits and Systems, Volume:32, Issue: 8, pp.1177-1186, 2013

[4] Kyungtae Han, et.al., " A hybrid display frame buffer architecture for energy efficient display subsystems", IEEE International Symposium on Low Power Electronics and Design (ISLPED), 2013, pp.347-353.

[5] T Das, B Pandey, Md A Rahman, T Kumar "SSTL Based Green Image ALU Design on different FPGA", IEEE International conference on Green Computing, Communication and Conservation of Energy(ICGCE), 2013.

[6] A. Motten, L. Claesen, Y. Pan, "Adaptive memory architecture for real-time image warping", IEEE 30th International Conference on Computer Design (ICCD), Page(s): 466 - 471, 2012.

[7] K. Haghdad, M. Anis, "Power Yield Analysis Under Process and Temperature Variations", IEEE Transactions on Very Large Scale Integration (VLSI) Systems, Volume:20, Issue: 10, pp. 17941803, 2012

[8] E.K. Ardestani, F.J. Martinez, G. Southern, E. Ebrahimi, J. Renau, "Sampling in Thermal Simulation of Processors: Measurement, Characterization, and Evaluation", IEEE Transactions on Computer-Aided Design of Integrated Circuits and Systems, Volume:32, Issue: 8, pp. 1187-1200, 2013. 